\title{
Study on the relativity between psychological contract and performance of the bookstore staff
}

\author{
Meina Zhang ${ }^{1, a^{*}}$ \\ ${ }^{1}$ Dalian Polytechnic University, Department of Management, No.1 Qing Gongyuan, Dalian, China \\ a274373684@qq.com
}

\begin{abstract}
Keywords: psychological contract; human resources; organizational performance; bookstore staff Abstract. Psychological contract is a kind of psychological ligament which exists between employees and organizations, playing an important role in job performance. To make human resource policies realistically and feasibly, it is necessary to use psychological contract to know what the employees expect of their organizations. This paper, with the purpose of solving the present problems, may fill the lack of theoretical model on the relationship between the psychological contract and staff performance. This is on the basis of the theory of management psychological theory and treats the organizational promise and job performance as the media variable. We tries to cause a heuristic argument and explore the relationship between psychological contract and job performance. Through analysis the impact of the bookstore staff's psychological contract on organizational performance, we put forward specific recommendations.
\end{abstract}

\section{Introduction}

In the current rapidly changing social circumstances, enterprise development and management do not fit obviously. Characteristics of psychological contract are the most sensitive factors. Honesty and trust which exist between enterprises and employees are contents of psychological con-tract, and also the implementation conditions of psycho-logical contract management. Therefore, improving management level of staff's psychological contract helps to improve staff satisfaction and passions, then it will enhance competitiveness and performance of enterprise.

\section{Defining psychological contract}

Psychological contract was put forward by Mercy who was the famous management psychologist professor in United States. It can be described as the relationship between the development of enterprise and staff, although no contract, enterprises and employees can find decisions of their respective focus. It means that enterprises can clear expectation for staff's development and meet them. Psychological contract is the hope that through close cooperation reach a mutual honesty, integration phase which are invisible frequency resonances and harmonious results.

Domestic scholar Jiazhou Chen[1] on the base of trade relationship, studied dimensions of psychological contract. On the basis of practical evidence, this paper considers that the three dimensional structure is more in line with requests. It concludes transaction, relationship and team members[2].

\section{Defining job performance}

Over the years, people define differently for individual performance. The focus of the debate is the result or action[3]. Bernardin tended to be representative of performance is equivalent to the result, so he defined as: within the specific time, performance is a record of output which produced by a specific job or activity. And Campbell and Murphy tended to take performance as the representative of the behavior. They defined performance as: performance are the upgrade action, behavior and output which are from organization when there is the same goal between organization and employees.

Relationship between psychological contract and performance

As the economy's growing, intense competition make the relationship within the employment undergone tremendous changes, and psychological balance continuously break down. People work effectively and have a sense of duty, loyalty to the organization, long-term development goals and 
enthusiasm or not, and whether they get satisfaction from their work, organizations management for employee performance[4].

When these psychological requirements are met, the greatest mobilization of enthusiasm from deep inside will come out. Organization should try to improve the working environment and the available resources[5]. On the basis of making thorough investigations and studies, and establishing good relationship of psychological contract and their basic needs, it is able to mobilize the enthusiasm and maximize performance of their staff. Only in this way can we truly produce and receive good incentive effects.

\section{Method}

\section{Participants and design}

For the purposes of this paper, I studied relevant literature and development theory deeply. Empirical research has shown that psychological contracts made up of three dimensions. The object of this thesis is the staff of Xinhua Bookstore in Shenyang. This questionnaires issued 100 and recycled 93. The rate of recovery was $93 \%$ and the rate of efficiency was $91 \%$.

Table 1. data analysis

\begin{tabular}{|c|c|c|c|}
\hline \multirow[b]{2}{*}{ Demographic variables } & \\
\hline & Category & Number of people & Proportion $(\%)$ \\
\hline \multirow[b]{2}{*}{ Gender } & Male & 51 & $56 \%$ \\
\hline & Female & 40 & $44 \%$ \\
\hline \multirow{4}{*}{ Age } & 20-25 Years old & 13 & $14 \%$ \\
\hline & 26-30 Years old & 24 & $26 \%$ \\
\hline & 31-35 Years old & 37 & $41 \%$ \\
\hline & above36 Years old & 17 & $19 \%$ \\
\hline \multirow{3}{*}{ Current position } & General staff & 46 & $51 \%$ \\
\hline & Low-level management & 29 & $32 \%$ \\
\hline & Middle management & 16 & $18 \%$ \\
\hline \multirow{3}{*}{ Education } & Junior college & 38 & $42 \%$ \\
\hline & Undergraduate & 46 & $51 \%$ \\
\hline & Master & 7 & $8 \%$ \\
\hline \multirow{6}{*}{ Length of service } & Less than one year & 14 & $15 \%$ \\
\hline & $1-2$ years & 26 & $29 \%$ \\
\hline & $2-5$ years & 33 & $36 \%$ \\
\hline & 5-10years & 8 & $9 \%$ \\
\hline & 10-20years & 7 & $8 \%$ \\
\hline & above 20 years & 3 & $3 \%$ \\
\hline
\end{tabular}

Analysis

Table 2 describes the relationship between transaction dimension and performance, and the value of the Pear-son Correlation represents a significant degree of correlation. This value is less than 0.5 which describes the relationship between transaction dimension and performance is not obvious.

Table 2. relationship between transaction dimension and performance

\begin{tabular}{|l|l|l|}
\hline & Transaction dimension & Performance \\
\hline Transaction dimension & 1 & 0.357 \\
Pearson Correlation Sig.(2-tailed) &. & .138 \\
N & 91 & 91 \\
\hline Performance & 0.357 & 1 \\
Pearson Correlation Sig.(2-tailed) & .138 &. \\
N & 91 & 91 \\
\hline
\end{tabular}

Table 3 describes the relationship between relationship dimension and performance, and the value of the Pear-son Correlation represents a significant degree of correlation. The value is greater than 0.5 which means there is a certain relationship between the relationship dimension and performance. 
Table 3. relationship between relationship dimension and performance

\begin{tabular}{|c|c|c|}
\hline & Relationship dimension & Performance \\
\hline $\begin{array}{llll}\text { Relationship } & \text { dimension } & \text { Pearson } & \text { Correlation } \\
\text { Sig.(2-tailed) } & & & \\
\text { N } & & \\
\end{array}$ & $\begin{array}{l}1 \\
91\end{array}$ & $\begin{array}{l}0.527 \\
.233 \\
91\end{array}$ \\
\hline $\begin{array}{l}\text { Performance Pearson Correlation } \\
\text { Sig.(2-tailed) } \\
\quad \text { N }\end{array}$ & $\begin{array}{l}0.527 \\
.233 \\
91 \\
\end{array}$ & $\begin{array}{l}1 \\
91 \\
\end{array}$ \\
\hline
\end{tabular}

Table 4 describes the relationship between team members and performance, the value of the Pearson Correlation represents a significant degree of correlation. The value is greater than 0.5 which means there is a certain relation-ship between the team members and performance.

Table 4. relationship between team member and performance

\begin{tabular}{|c|l|l|}
\hline & Dimension of team members & Performance \\
\hline Team members Pearson Correlation & 1 & 0.703 \\
Dimensions Sig.(2-tailed) &. & .000 \\
N & 91 & 91 \\
\hline Performance Pearson Correlation & 0.703 & 1 \\
Sig.(2-tailed) & .000 &. \\
N & 91 & 91 \\
\hline
\end{tabular}

From the above three charts, transaction dimension, the relationship dimension, and team member have a certain relationship with performance. Particularly, team members has reached 0.703 which means relationship is very significant. It has a certain impact on performance.

\section{Discussion}

Three dimensions of psychological contract have an impact on staff performance, but it is different. In fact, the creation and improvement of psychological contract between bookstore and staff is a system engineering. How to establish a performance management system based on psychological contract has been an important issue which is worthy of discussion on staff who focus on human resources[6].

Firstly, construction of performance management must be based on psychological contract from the initial stage. Bookstore encourages employees to foster a positive work attitude and high standard of work. This invisible guidance and traction support bring the new achievements and new standards. According to their own personal expectations and bookstore vision objectives, new staff adjust their own psychological needs in a timely manner and determine their reasonable career planning, along with the development of enterprises.

Secondly, one of the core factors of the construction of psychological contract is to understand and meet the internal needs of employees. According to organizational behavior theory, the essence of performance management is that staff achieve organizational goals through the quality of the work effort, and that efforts meet employee needs in various aspects of the subject of the premise. From the practices of human resources management, enterprises should meet their individual needs, including arrangements for work, salary system and other aspects of management.

Finally, the construction of psychological contract of performance management must be on the precondition of scientific occupation career management[7]. As a bookstore for profit-making purposes, its rapid growth and development will always be in a dynamic process and the relationship between the organization and its internal members are also in a subtle and changeable state. In order to establish performance management model based on psychological contract effectively, organizations need to help employees set career goals on the basis of the combination between organizations and individuals. Then organizations determine their long-term and short-term career goals and method of judging properly. Meanwhile, bookstore should also ensure that established target is specifically achievable and challenging. They should assist the staff to achieve the goal of occupation. The 
construction of psychological contract of the employee and enterprise is a pivotal task. It is the driving force with enterprise performance improvement.

\section{Conclusion}

Through the analysis of the questionnaire data, we analysis the correlation between the three dimensions of psychological contract and employee performance and summary effects of bookstore employees' psychological contract on organization performance. Building good psychological contract is not a part of management, but is an important task of the throughout process of the whole enterprise management[8]. In particular, in all areas of human resources management, such as recruitment and selection, training and development, performance evaluation, motivation and staff work with the enterprise and in the construction of inter-personal relationships, everything you want to focus on building good psychological contract between the enterprise and the employees.

\section{Practical significance}

Chinese market-oriented economy continue to strengthen and relationship in the employment has undergone tremendous changes. This paper can highlight the recessive psychological contract affection on performance, through empirical investigations and data analysis, put forward the effect of employee psychological contract on performance and the degree of influence, and opinions about psychological contract terms. By increasing the management level, this helps to keep the excellent staff, improve staff morale, give play to the staff's passion to create, and enhance the overall competitiveness of the organization.

\section{Theoretical significance}

Most companies in China are still very strange on the psychological contract management, there is no denying that psychological contract is the regulator of economic contract between enterprises and employees, it is no less importance than the economic contract. Psychological contract as associate link between staff and the organization, will affect the employee's work performance. Because of these characteristics, it make psychological contracts management more difficult than the economy contract. But if organizations manage properly, it is the lubricant of regulating relations of employees and business and achieve win-win.

\section{References}

[1] Jiazhou Chen, Wenquan Ling, Liluo Fang. Psychological contract of Organization, Journal of Management Science, 2001.

[2] Yuan Li, Dejun Guo. Psychological contract of Organization [J] Psychological Science Progress, vol. 1, 2002.

[3] Chen $\mathrm{Yu}$. The research status and Prospect of domestic psychological contract, Economic Forum, 2004.

[4] Zhican Zhang, Liluo Fang, Wenshuan Ling, Employee organizational commitment, China Management Sciences, 1997, 5 (1): 46-50.

[5] Rousseau, D M, Park, J M. The contract of individuals and organizations, Research Organizational Behavior, 1993, (1).

[6] Chunyong Tang. Analysis of the relationship between personality, attitude and performance, Academic Studies, 2006, (5).

[7] Radinowitz, Hall, D T. Organizational Research on Job Involvement, Psychological Bulletin, 1977, 84(2): 265-288. 
[8] Burton J P, Lee T W, Hotom B C. The Influence of Motivation to Attend, Ability to Attend, and Organizational Commitment on Different Types of Absence Behaviors, Journal of Managerial Issues, 2002, 11(2): 181-197. 